\title{
Mortality and incidence of cancer at four factories making phenoxy herbicides
}

\author{
David Coggon, Brian Pannett, Paul Winter
}

\begin{abstract}
To assess the possible carcinogenicity of phenoxy herbicides and related chlorophenols and dioxins, the International Agency for Research on Cancer is coordinating an international collaborative study of workers exposed to these compounds in their production or use. Four British cohorts of chemical manufacturers which have been recruited to the survey are described. They comprise a total of 2239 men employed during 1963-85. These subjects were traced to 31 December 1987 through the National Health Service Central Register and the National Insurance Index, and their mortality compared with that in the national population. Two deaths were from nonHodgkin's lymphoma with 0.87 expected. Both deaths occurred more than 10 years after first exposure to phenoxy compounds. One further non-Hodgkin's lymphoma was registered in a living subject with probable exposure to phenoxy compounds. No cases of soft tissue sarcoma or Hodgkin's disease were recorded. A nonsignificant excess of lung cancer (19 deaths observed, 14.2 expected) is probably attributable to chance or a confounding effect of smoking. In one cohort only there was increased mortality from circulatory disease (34 deaths observed, 20.4 expected). A nested case-control study did not point to any occupational cause for this excess, but further evaluation will be needed during continued follow up.
\end{abstract}

The regulation of pesticides requires that the utility of products be balanced against any risks to the environment and to the health of manufacturers,

MRC Environmental Epidemiology Unit, University of Southampton, Southampton General Hospital, Southampton SO9 4XY

D Coggon, B Pannett, P Winter users, and those eating contaminated foods. Judgements about the toxicity of new compounds in man are usually based on extrapolation from laboratory experiments in vitro and in animals. Many pesticides have now been in use long enough, however, that it is possible to assess even their chronic effects more directly. Such assessment is important because laboratory investigation may not always reliably predict toxicity in man.

One group of compounds that have attracted particular attention are the phenoxy herbicides (for example, 2,4,5-trichlorophenoxyacetic acid $(2,4,5-$ T), 2,4-dichlorophenoxyacetic acid (2,4-D), 2 methyl-4 chlorophenoxyacetic acid (MCPA)). Discovered in the 1940s, these chemicals have found extensive worldwide use in agriculture and forestry, as well as being sold on a smaller scale for domestic application in gardens. Initial case-control studies in Sweden suggested that exposure to phenoxy compounds and structurally related chlorophenols might carry an increased risk of soft tissue sarcoma ${ }^{12}$ and lymphoma. ${ }^{3}$ This idea was supported by the findings of four cohort studies of chemical manufacturers in the United States. ${ }^{4-7}$ Subsequent investigations, however, have been less conclusive. ${ }^{8-22}$ Several have shown associations between the manufacture or use of phenoxy compounds and soft tissue sarcoma or lymphoma, but risk estimates have been smaller than in the earlier studies and usually not statistically significant.

The statistical uncertainty surrounding small increases in risk for rare diseases presents a problem in evaluation. To help resolve this issue, the International Agency for Research on Cancer (IARC) has established an international collaborative survey of workers exposed to phenoxy acids and related compounds. ${ }^{23}$ The study includes cohorts from six British companies. Data on two have already been published. ${ }^{1424}$ Here we describe the other four British workforces in the IARC survey, and report their mortality and cancer incidence. The findings are relevant not only to the assessment of phenoxy compounds but also to other chemicals that have been manufactured and formulated at the same factories. 
Table 1 Definition of cohort

\begin{tabular}{|c|c|c|c|c|c|}
\hline Factory & $\begin{array}{l}\star \text { Phenoxy herbicides and } \\
\text { chlorophenols produced and } \\
\text { formulated (unless otherwise } \\
\text { stated, dates are for both } \\
\text { production and formulation) }\end{array}$ & Other main products & $\dagger$ Definition of cohort & $\begin{array}{l}\text { Number of } \\
\text { men } \\
\text { analysed }\end{array}$ & $\begin{array}{l}\text { Number } \\
\text { men } \\
\text { traced }\end{array}$ \\
\hline $\mathrm{A}$ & $\begin{array}{l}\text { 2,4,5-T } 1968-78 \\
2,4-\mathrm{D} \text { and } 2,4-\mathrm{DP} 1954- \\
2,4-\mathrm{DB} 1965- \\
\text { MCPA and MCPP } 1954- \\
\text { MCPB } 1970- \\
\text { PCPA and PAA (produced only) } 1969-\end{array}$ & $\begin{array}{l}\text { Picric acid } \\
\text { Dinitro-o-butyl phenol } \\
\text { Dinitro-o-cresol } \\
\text { Simazine } \\
\text { Aminotriazole } \\
\text { Oxynils }\end{array}$ & $\begin{array}{l}\text { All manual employees } \\
\text { during April 1975- } \\
\text { October } 1985\end{array}$ & 1104 & 1082 \\
\hline B & $\begin{array}{l}\text { 2,4,5-T (formulated only) 1970-74 } \\
\text { 2,4-D, 2,4-DP and 2,4-DB 1969- } \\
\text { MCPA and MCPP 1969- } \\
\text { MCPB formulated 1969- } \\
\text { produced } 1975-\end{array}$ & $\begin{array}{l}\text { Dithiocarbamates } \\
\text { Organophosphorus compounds } \\
\text { Carbamates } \\
\text { Dinocap } \\
\text { Toluidine compounds } \\
\text { Urea herbicides } \\
\text { Imidazole compounds } \\
\text { Phthalimide compounds }\end{array}$ & $\begin{array}{l}\text { All weekly paid employees } \\
\text { during March 1969- } \\
\text { November } 1985\end{array}$ & 271 & 261 \\
\hline $\mathrm{C}$ & $\begin{array}{l}2,4,5-\mathrm{T} \text { (formulated only) 1959-81 } \\
2,4,-\mathrm{D} \text { (formulated only) 1959-81 } \\
\text { MCPB } 1956- \\
\text { PBA (produced only) } 1958-75\end{array}$ & $\begin{array}{l}\text { Aminophylline } \\
\text { Metronidazole } \\
\text { Sulphonamides } \\
\text { Oxynils } \\
\text { Dinocap } \\
\text { Asulam } \\
\text { Sodamide } \\
\text { Diflufenican }\end{array}$ & $\begin{array}{l}\text { (1) All process workers on } \\
\text { the phenoxy plant during } \\
\text { January 1963-December } \\
1984 \\
\text { (2) All formulators and packers } \\
\text { during January 1982- } \\
\text { December } 1984 \\
\text { (3) All maintenance workers } \\
\text { during July } 1967- \\
\text { December } 1984\end{array}$ & 345 & 343 \\
\hline $\mathrm{D}$ & $\begin{array}{l}\text { 2,4,5-T (formulated only) } 1960-79 \\
\text { 2,4-D 1949- } \\
\text { 2,4-DP } 1955- \\
\text { MCPA 1951- } \\
\text { MCPP produced 1955- } \\
\text { formulated 1965- } \\
\text { 2,4,6-TCP (produced only) } 1983-\end{array}$ & $\begin{array}{l}\text { Metallic soaps } \\
\text { Plasticiser esters } \\
\text { Naphthenic acid } \\
\text { Alkyl phenols } \\
\text { Phthalate esters }\end{array}$ & $\begin{array}{l}\text { All weekly paid employees } \\
\text { during April } 1969- \\
\text { December } 1985\end{array}$ & 519 & 503 \\
\hline
\end{tabular}

$\star 2,4,5-\mathrm{T}=2,4,5$-Trichlorophenoxyacetic acid, 2,4-D =2,4-dichlorophenoxyacetic acid, 2,4-DP=2,4-dichlorophenoxypropionic acid, 2,4-DB = 2. dichlorophenoxybutyric acid, $M C P A=2$ methyl-4 chlorophenoxyacetic acid, $M C P P=2$ methyl-4 chlorophenoxpropionic acid, $M C P B=2$ meth chlorophenoxybutyric acid, PCPA= parachlorophenoxyacetic acid, PAA=phenoxyacetic acid, PBA=phenoxybutyric acid, 2,4,6-TCP=2, trichlorophenol.

†As only one woman met these criteria, the study was restricted to men.

\section{Method}

Subjects worked at four factories each of which manufactured and formulated a range of chemicals including phenoxy herbicides (table 1). The compound 2,4,5-T was produced at factory $\mathrm{A}$ during 1968-78, but at the other factories it was only formulated. Manufacturing processes were similar at all four factories. The relevant substituted phenol was reacted with monochloroacetic acid to produce phenoxyacetic compounds, with $\alpha$-chloropropionic acid to make phenoxypropionic compounds, and with $\gamma$-butyrolactone to produce phenoxybutyric compounds. The 2,4,6-trichlorophenol was synthesised at factory $\mathrm{D}$ by chlorination of dichlorophenol.

Table 1 sets out the criteria for entry to the cohort. Scope for recruitment was limited by the availability of complete records from which subjects could be identified. At factories A, B, and D information was obtained from personnel or wages files. At factory C process and maintenance workers were identified from bound registers kept by shift foremen, and formulators and packers from personnel records. For each member of the cohort we abstracted (as far as they were available) the name, date of birth, address, national insurance number, and job history.

Job histories were used to classify subjects according to their potential exposure to phenoxy compounds and chlorophenols. At factories $\mathrm{A}$ and D records were sufficiently detailed to distinguish jobs that entailed work with these chemicals. The few subjects who worked only in,non-phenoxy plants were considered to have only "background" exposure. At factory $\mathrm{C}$ process operators were identified from the shift register on the phenoxy plant, and thus are known to have worked with phenoxy compounds. Maintenance workers and formulators and packers were also considered to be exposed, although a few may not have come into contact with the compounds if they only worked in the job for a short period. The employment records at Factory B 
Table 2 Observed and expected mortality by cause: all subjects

\begin{tabular}{|c|c|c|c|c|c|c|c|}
\hline \multirow[b]{2}{*}{ Cause of death } & \multirow[b]{2}{*}{$\begin{array}{l}\text { Deaths } \\
\text { observed }\end{array}$} & \multicolumn{3}{|c|}{ Analysis based on national rates } & \multicolumn{3}{|c|}{ Expected numbers locally adjusted } \\
\hline & & $\begin{array}{l}\text { Deaths } \\
\text { expected }\end{array}$ & $S M R$ & $95 \% C I$ & $\begin{array}{l}\text { Deaths } \\
\text { expected }\end{array}$ & $S M R$ & $95 \% C I$ \\
\hline $\begin{array}{l}\text { All causes } \\
\text { Circulatory disease } \\
\text { Respiratory disease } \\
\text { Injury and poisoning } \\
\text { All cancer } \\
\text { Cancer of lung } \\
\text { Soft tissue sarcoma } \\
\text { Hodgkin's disease } \\
\text { Non-Hodgkin's lymphoma }\end{array}$ & $\begin{array}{r}152 \\
74 \\
8 \\
19 \\
37 \\
19 \\
0 \\
0 \\
2\end{array}$ & $\begin{array}{r}136 \cdot 22 \\
63 \cdot 76 \\
11 \cdot 78 \\
12 \cdot 27 \\
36 \cdot 84 \\
14 \cdot 15 \\
0 \cdot 18 \\
0 \cdot 43 \\
0 \cdot 87\end{array}$ & $\begin{array}{r}112 \\
116 \\
68 \\
155 \\
100 \\
134 \\
0 \\
0 \\
229\end{array}$ & $\begin{array}{l}94-131 \\
91-146 \\
29-134 \\
93-242 \\
71-138 \\
81-210 \\
0-2087 \\
0-855 \\
28-827\end{array}$ & $\begin{array}{r}134 \cdot 73 \\
63.94 \\
11 \cdot 74 \\
11 \cdot 06 \\
36.66 \\
14 \cdot 21 \\
0 \cdot 18 \\
0.38 \\
0.73\end{array}$ & $\begin{array}{r}113 \\
116 \\
68 \\
172 \\
101 \\
134 \\
0 \\
0 \\
272\end{array}$ & $\begin{array}{c}96-132 \\
91-145 \\
29-134 \\
103-268 \\
71-139 \\
80-209 \\
0-2058 \\
0-976 \\
33-983\end{array}$ \\
\hline
\end{tabular}

Deaths were also observed from cancer of mouth (1), oesophagus (1), stomach (2), small intestine (1), large intestine (2), rectum (2), bowel not further specified (1), pancreas (2), larynx (1), bone (1), testis (1), and bladder (1).

did not distinguish between work on different processes, and individual exposures therefore could not be assigned with confidence. Management estimated that approximately $50 \%$ of employees would have worked with phenoxy compounds during campaign periods (January-May), but all staff were likely to walk through the production areas on occasions. No environmental or personal monitoring for phenoxy compounds, chlorophenols, or contaminant dioxins had been carried out at any of the factories.

Subjects were traced through the National Health Service Central Register and National Insurance Index up to 31 December 1987. For those who had died we obtained a copy of the death certificate with the underlying cause of death coded to the ninth revision of the International Classification of Diseases. We were also notified of any cancers registered among living members of the cohort.

Mortality ratios standardised for age (in five year bands), sex, and five year calendar period of death were calculated by the person-years method with rates for England and Wales as standard. In some analyses a second set of mortality ratios was derived with expected numbers of deaths for each factory adjusted in proportion to standardised mortality ratios (SMRs) during 1974-85 for the local authority area in which the factory was situated. Confidence intervals for mortality ratios were based on the Poisson distribution.

\section{Results}

A total of 2256 men satisfied the criteria for entry to the cohort, but 17 had to be excluded from the analysis because their date of birth was unavailable. Of the remaining 2239 men, 2189 (97.8\%) were traced, including 152 who had died and 19 who had emigrated. These 19 were followed up to the date that they left the country, while untraced subjects were considered to be at risk up to their last known date of employment. Table 1 shows the numbers of men traced from each factory.

Table 2 shows mortality by cause for the full cohort. The total of deaths observed during the follow up period was a little higher than expected from national rates, and this was due largely to excesses of circulatory disease $(S M R=116,95 \% \mathrm{CI}$ 91-146) and of deaths from injury and poisoning $(\mathrm{SMR}=155,95 \%$ CI 93-242). Overall cancer mortality was close to expectation, but there was a small excess of deaths from lung tumours (19 observed $v 14 \cdot 15$ expected). Two deaths from nonHodgkin's lymphoma were recorded compared with

Table 3 Mortality by factory for selected causes

\begin{tabular}{|c|c|c|c|c|c|c|c|c|}
\hline \multirow[b]{2}{*}{ Cause of death } & \multicolumn{2}{|c|}{ Factory $A$} & \multicolumn{2}{|c|}{ Factory $B$} & \multicolumn{2}{|c|}{ Factory $C$} & \multicolumn{2}{|c|}{ Factory D } \\
\hline & $\begin{array}{l}\text { Deaths } \\
\text { observed }\end{array}$ & $\begin{array}{l}\text { Deaths } \\
\text { expected }\end{array}$ & $\begin{array}{l}\text { Deaths } \\
\text { observed }\end{array}$ & $\begin{array}{l}\text { Deaths } \\
\text { expected }\end{array}$ & $\begin{array}{l}\text { Deaths } \\
\text { observed }\end{array}$ & $\begin{array}{l}\text { Deaths } \\
\text { expected }\end{array}$ & $\begin{array}{l}\text { Deaths } \\
\text { observed }\end{array}$ & $\begin{array}{l}\text { Deaths } \\
\text { expected }\end{array}$ \\
\hline All causes & 62 & $44 \cdot 70$ & 17 & 11.90 & 22 & $30 \cdot 13$ & 51 & $49 \cdot 50$ \\
\hline Circulatory disease & 34 & $20 \cdot 42$ & 5 & $5 \cdot 29$ & 12 & $14 \cdot 31$ & 23 & $23 \cdot 75$ \\
\hline Respiratory disease & 1 & 3.41 & 1 & $1 \cdot 25$ & 0 & $2 \cdot 33$ & 6 & 4.79 \\
\hline Injury and poisoning & 7 & $4 \cdot 77$ & 3 & 1.43 & 3 & 2.59 & 6 & 3.48 \\
\hline All cancer & 12 & $12 \cdot 26$ & 5 & $2 \cdot 83$ & 6 & $8 \cdot 34$ & 14 & $13 \cdot 42$ \\
\hline Cancer of lung & 6 & 4.63 & 3 & 0.99 & 4 & $3 \cdot 22$ & 6 & $5 \cdot 30$ \\
\hline Non-Hodgkin's lymphoma & 0 & $0 \cdot 31$ & 0 & 0.07 & 1 & 0.20 & 1 & 0.29 \\
\hline
\end{tabular}

Expected numbers are based on national rates. 
Table 4 Mortality from selected causes in men at Factories $A, C$, and $D$ with greater than background exposure to phenoxy compounds and/or chlorophenols

\begin{tabular}{|c|c|c|c|c|}
\hline \multirow[b]{2}{*}{ Cause of death } & \multicolumn{2}{|c|}{$\begin{array}{l}\text { Subjects followed up from first exposure } \\
\text { above background }\end{array}$} & \multicolumn{2}{|c|}{$\begin{array}{l}\text { Subjects followed up from } 10 \text { years after first } \\
\text { exposure above background }\end{array}$} \\
\hline & $\begin{array}{l}\text { Deaths } \\
\text { observed }\end{array}$ & $S M R$ & $\begin{array}{l}\text { Deaths } \\
\text { observed }\end{array}$ & $S M R$ \\
\hline $\begin{array}{l}\text { Circulatory disease } \\
\text { All cancer } \\
\text { Cancer of lung } \\
\text { Non-Hodgkin's lymphoma }\end{array}$ & $\begin{array}{r}59 \\
30 \\
14 \\
2\end{array}$ & $\begin{array}{l}117 \\
102 \\
123 \\
282\end{array}$ & $\begin{array}{r}31 \\
13 \\
6 \\
2\end{array}$ & $\begin{array}{r}110 \\
80 \\
92 \\
588\end{array}$ \\
\hline
\end{tabular}

SMRs are based on national rates.

0.87 expected, but there were no deaths from Hodgkin's disease or soft tissue sarcoma. Adjustment for local differences in mortality had little effect on expected numbers.

Table 3 summarises mortality patterns by factory. The excesses of lung cancer and of injury and poisoning were spread across all factories, whereas the high rate of circulatory disease was confined to factory A (34 deaths observed $v 20.42$ expected). With adjustment for local mortality, the expected number of circulatory deaths at factory $\mathrm{A}$ rose to 24.49 , and the excess fell just short of statistical significance at a $5 \%$ level. The two deaths from nonHodgkin's lymphoma occurred at factories $\mathrm{C}$ and $\mathrm{D}$.

Table 4 shows mortality ratios for subjects at factories $\mathrm{A}, \mathrm{C}$, and $\mathrm{D}$ with more than background exposure to phenoxy compounds or chlorophenols. Standardised mortality ratios for circulatory disease and all cancers were similar to those for the full cohort, whereas that for lung cancer was rather lower, especially after allowance for a latency of 10 years from first exposure. The two cases of nonHodgkin's lymphoma both occurred more than 10 years after first exposure to levels above background-one man had been a packer for 21 years and the other a process operator in phenoxy acid synthesis for one month.

Only one further case of non-Hodgkin's lymphoma had been registered among living members of the cohort-a process worker at factory B. There were no registrations of Hodgkin's disease or soft tissue sarcoma.
Eight of the 19 deaths from injury and poisoning occurred while the men concerned were still working at the factories under study. Of these, two were due to accidents at work, two to accidents outside work, three to suicide or possible suicide, and one to homicide.

To investigate further the excess of circulatory disease at factory A, we carried out a nested casecontrol study. Each of the 34 cases at the factory was matched with four controls who were under follow up at the time that the case died, and whose date of birth was as close as possible to that of the case. Year of birth was matched to within one year for $82 \%$ of controls, and the mean year of birth of controls was one year later than that of cases. Associations with having ever worked in various departments were examined by conditional logistic regression for matched sets. ${ }^{25}$ Table 5 summarises the findings. No individual department was clearly associated with a risk of circulatory disease. Risk was significantly increased among the aggregate of smaller departments (the 'other' category in table 5), but detailed examination did not suggest a common underlying factor.

\section{Discussion}

Although the workforces that we studied were exposed to a multiplicity of chemicals, this only presents a problem of interpretation in relation to positive findings. Any reassurance deriving from

Table 5 Risk of circulatory disease at Factory $A$ according to department

\begin{tabular}{|c|c|c|c|c|}
\hline \multirow[b]{2}{*}{ Department } & \multicolumn{2}{|c|}{ Subjects ever employed in department } & \multirow[b]{2}{*}{ Relative risk } & \multirow[b]{2}{*}{$95 \% C I$} \\
\hline & Cases $(n=34)$ & Controls $(n=136)$ & & \\
\hline Oxynils & 0 & 16 & 0 & - \\
\hline Nitration products & 1 & 1 & $4 \cdot 0$ & $0 \cdot 3-64 \cdot 0$ \\
\hline Triazines & 0 & 4 & 0 & - \\
\hline Engineering & 4 & 19 & $0 \cdot 8$ & $0.3-2 \cdot 6$ \\
\hline Effluent & 2 & 8 & $1 \cdot 0$ & $0 \cdot 2-4.7$ \\
\hline Plant cleaning & 2 & 5 & 1.6 & $0 \cdot 3-8 \cdot 2$ \\
\hline Other & 15 & 19 & $6 \cdot 2$ & $2 \cdot 3-16 \cdot 4$ \\
\hline
\end{tabular}


risks which were not increased extends to all exposures experienced by the cohort. Unfortunately, levels of exposure to specific chemicals could not be precisely estimated. In particular, no hygiene data were available for phenoxy compounds, for the chlorophenols from which they were made, or for the dioxins with which they may have been contaminated. From descriptions of processes and methods of operation provided by longstanding employees, however, we estimate that exposures during the early part of the study period would generally have been higher than more recently. Thus, any risks from current working practices at the factories are likely to be lower than those in the workers studied.

No soft tissue sarcomas or Hodgkin's lymphomas were recorded in the study cohort during the period of follow up. There were, however, two deaths from non-Hodgkin's lymphoma compared with 0.87 expected, and one further case was registered in a subject who was still alive. Expected numbers of incident cancers could not be reliably estimated because the completeness of cancer registration in Britain has varied between regions and over time, but our findings accord with those of most previous studies in suggesting that any risk of soft tissue sarcoma or lymphoma from occupational contact with phenoxy compounds is small. ${ }^{8-22} \mathrm{~A}$ more precise estimate of the risk of these rare tumours will be possible from analysis of the full IARC survey with its much larger study population.

The largest excess of cancer found was for lung tumours (19 deaths observed $v 14.2$ expected), and this derived from all four factories. Most of the deaths occurred, however, less than 10 years after first exposure to phenoxy compounds or in subjects with only background exposure. After allowance for a latency of 10 years from first exposure, the increased risk disappeared (table 4). This and the absence of a comparable association with lung cancer in most other cohort studies of phenoxy workers 578141920 suggests that phenoxy compounds are unlikely to be responsible for the excess. A more likely explanation is chance or a confounding effect of smoking. Data on the smoking habits of cohort members were not available.

The only diagnostic category for which we found a clear increase in risk was circulatory disease, and this was confined to factory A where 34 deaths were observed $v 24.5$ expected (after adjustment for local patterns of mortality). The finding is particularly remarkable since occupational cohorts usually exhibit a deficit of cardiovascular deaths because of the healthy worker effect. The limitation of the excess to one factory and the absence of similar associations in other cohorts of phenoxy workers $^{5141920}$ argue against a hazard from the phenoxy process, but it was possible that some other aspect of work at factory $\mathrm{A}$ might be responsible. We therefore carried out a nested case-control study to examine other possible occupational risk factors, but could find none that would explain the observation. The excess could perhaps be due to a combination of smoking and other non-occupational causes, but it will require further evaluation during continued follow up.

Despite the limitations imposed by small numbers and the potential difficulties in unravelling the effects of multiple exposures, it is important that studies such as this are carried out. They provide an essential audit of the extrapolation from laboratory data on which most decisions for the regulation of pesticides are based. We will continue to follow up these workforces and review their mortality and cancer incidence at intervals.

We thank the staff of the NHS Central Register and the National Insurance Index for their assistance in tracing subjects and Rosemarie Kirby for her help with the computing. The study was supported by a grant from the International Agency for Research on Cancer.

\section{Requests for reprints to: Dr D Coggon.}

1 Hardell L, Sandstrom A. Case-control study: soft tissue sarcomas and exposure to phenoxyacetic acids or chlorophenols. Br J Cancer 1979;39:711-7.

2 Eriksson M, Hardell L, Berg NO, Moller T, Axelson O. Soft tissue sarcomas and exposure to chemical substances: a casereferent study. Br J Ind Med 1981;38:27-33.

3 Hardell L, Eriksson M, Lenner P, Lundgren E. Malignant lymphoma and exposure to chemicals, especially organic solvents, chlorophenols and phenoxy acids: a case-control study. $\mathrm{Br} J$ Cancer 1981;43:169-76.

4 Honchar PA, Halperin WE. 2,4,5-T, trichlorophenol and soft tissue sarcomas. Lancet $1981 ; \mathbf{i}: 268-9$.

5 Zack JA, Suskind RR. The mortality experience of workers exposed to tetrachlorodibenzodioxin in a trichlorophenol process accident. J Occup Med 1980;22:11-4.

6 Cook RR, Townsend JC, Ott G, Silverstein LG. Mortality experience of employees exposed to 2,3,7,8-tetrachlorodibenzo-p-dioxin (TCDD). J Occup Med 1980;22:530-2.

7 Ott MG, Holder BB, Olson RD. A mortality analysis of employees engaged in the manufacture of 2,4,5-trichlorophenoxyacetic acid. J Occup Med 1980;22:47-50.

8 Riihimaki V, Asp S, Hernberg S. Mortality of 2,4-dichlorophenoxyacetic acid and 2,4,5-trichlorophenoxyacetic acid herbicide applicators in Finland. Scand $J$ Work Environ Health 1982;8:37-42.

9 Lathrop GD, Moynahan PM, Albanese RA, Wolfe WH. An epidemiologic investigation of health effects in airforce personnel following exposure to herbicides: baseline mortality study results. Brooks Air Force Base, Texas: United States Air Force School of Aerospace Medicine, 1983.

10 Greenwald P, Kovasznay B, Collins DN, Therriault G. Sarcomas of soft tissues after Vietnam service. J Natl Cancer Inst 1984;73:1107-9.

11 Smith AH, Pearce NE, Fisher DO, Giles HJ, Teague CA, Howard JK. Soft tissue sarcoma and exposure to phenoxy herbicides and chlorophenols in New Zealand. $J$ Natl Cancer Inst 1984;73:1111-7.

12 Royal Commission on the Use and Effects of Chemical Agents on Australian Personnel in Vietnam. Final report July 1985. Vol 4. Canberra: Australian Government Publishing Service, 1985.

13 Lynge $\mathrm{E}$. A follow-up study of cancer incidence among workers in manufacture of phenoxy herbicides in Denmark. $\mathrm{Br} J$ Cancer 1985;52:259-70. 
14 Coggon D, Pannett B, Winter PD, Acheson ED, Bonsall J. Mortality of workers exposed to 2-methyl-4-chlorophenoxyacetic acid. Scand J Work Environ Health 1986; 12:448-54.

15 Hoar SK, Blair A, Holmes FF, et al. Agricultural herbicide use and risk of lymphoma and soft tissue sarcoma. JAMA 1986;256:1141-7.

16 Pearce NE, Smith AH, Howard JK, Sheppard RA, Giles HJ, Teague CA. Non-Hodgkin's lymphoma and exposure to phenoxy herbicides, chlorophenols, fencing work, and meat works employment: a case-control study. $\mathrm{Br} J$ Ind $\mathrm{Med}$ 1986;43:75-83.

17 Woods JS, Polissar L, Severson RK, Heuser LS, Kulander BG. Soft tissue sarcoma and non-Hodgkin's lymphoma in relation to phenoxy herbicide and chlorinated phenol exposure in western Washington. J Natl Cancer Inst 1987;78:899-910.

18 Veneis P, Terracini B, Ciccone G, et al. Phenoxy herbicides and soft tissue sarcomas in female rice weeders: A populationbased case-referent study. Scand $J$ Work Environ Health 1987;13:9-17.

19 Ott MG, Olson RA, Cook RR, Bond GG. Cohort mortality study of chemical workers with potential exposure to the higher chlorinated dioxins. J Occup Med 1987;29:422-9.
20 Bond GG, Wetterstroem NH, Roush GJ, McLaren EA, Lipps TE, Cook RR. Cause specific mortality among employees engaged in the manufacture, formulation, or packaging of 2,4dichlorophenoxyacetic acid and related salts. $\mathrm{Br} J$ Ind Med 1988;45:98-105.

21 Persson B, Dahlander A, Fredriksson M, Brage $\mathrm{HN}$, Ohlson CG, Axelson O. Malignant lymphomas and occupational exposures. Br J Ind Med 1989;45:516-20.

22 Eriksson M, Hardell L, Adami HO. Exposure to dioxins as a risk factor for soft tissue sarcoma: a population-based case-control study. J Natl Cancer Inst 1990;82:486-90.

23 Johnson ES, Winkelmann R, L'Abbe KA, et al. Phenoxy acid herbicides and contaminants: Description of the IARC international register of workers. Am J Ind Med 1990;18:39-45.

24 Bishop CM, Jones AH. Non-Hodgkins lymphoma of the scalp in workers exposed to dioxins. Lancet 1981;ii:369.

25 Breslow NE, Day NE. Statistical methods in cancer research. Vol 1. The analysis of case-control studies. Lyon: International Agency for Research on Cancer, 1980:248-79.

Accepted 1 October 1990

\section{Correspondence and editorials}

The British Journal of Industrial Medicine welcomes correspondence relating to any of the material appearing in the journal. Results from preliminary or small scale studies may also be published in the correspondence column if this seems appropriate. Letters should be not more than $\mathbf{5 0 0}$ words in length and contain a minimum of references. Tables and figures should be kept to an absolute minimum. Letters are accepted on the understanding that they may be subject to editorial revision and shortening.

The journal now also publishes editorials which are normally specially commissioned. The Editor welcomes suggestions regarding suitable topics; those wishing to submit an editorial, however, should do so only after discussion with the Editor. 